This item was submitted to Loughborough's Research Repository by the author.

Items in Figshare are protected by copyright, with all rights reserved, unless otherwise indicated.

\title{
Review on life cycle of parabens: synthesis, degradation, characterization and safety analysis
}

\section{PLEASE CITE THE PUBLISHED VERSION}

https://doi.org/10.2174/1385272822666180123150323

\section{PUBLISHER}

(C) Bentham Science

\section{VERSION}

AM (Accepted Manuscript)

\section{PUBLISHER STATEMENT}

This work is made available according to the conditions of the Creative Commons Attribution-NonCommercialNoDerivatives 4.0 International (CC BY-NC-ND 4.0) licence. Full details of this licence are available at: https://creativecommons.org/licenses/by-nc-nd/4.0/

\section{LICENCE}

CC BY-NC-ND 4.0

\section{REPOSITORY RECORD}

Yang, Huaiyu, Fan Zhang, and Han Wu. 2019. "Review on Life Cycle of Parabens: Synthesis, Degradation, Characterization and Safety Analysis”. figshare. https://hdl.handle.net/2134/37650. 


\title{
Review on life cycle of parabens: synthesis, degradation, characterization and safety analysis
}

\author{
Huaiyu Yang ${ }^{\mathrm{a}}$, Fan Zhang ${ }^{\mathrm{b} *}$ and Han $\mathrm{Wu}^{\mathrm{c} *}$ \\ ${ }^{a}$ Department of Chemical Engineering, Imperial College London, London, UK; ${ }^{b}$ Department of Chemical \\ Engineering and Science, Royal Institute of Technology KTH, Stockholm, Sweden Name, Faculty Name, \\ University Name, City, Country; ${ }^{b}$ Department of Chemical Engineering, University of College London, \\ London, UK
}

\begin{abstract}
In this review, we show the life cycle of parabens, commonly used preservatives that exist in nature and commercial products. Typical synthetic methods to produce parabens, and a set of complimentary characterization techniques to monitor the composition of parabens are also highlighted. These includes solid state analysis using Scanning Electron Microscope (SEM), Differential Scanning Calorimetry (DSC) and X-Ray Diffraction (XRD), in-situ monitoring of crystallization process using Focused Beam Reflectance Measurement (FBRM), Particle Vision Measurement (PVM), quantitative detection via High Performance Liquid Chromatography (HPLC), and Gas Chromatography (GC). An improved understanding of the overall physical, biophysical and chemical properties of parabens and their life cycle, summarized in this article, are vital for the safety control and extensive applications of relevant products in food, cosmetic and pharmaceutical industries.
\end{abstract}

Keywords: paraben; synthesis; degradation; characterization; safety; analysis;

\section{INTRODUCTION}

Parabens are a homologous series of alkyl esters of parahydroxybenzoic acid including Ethyl Paraben (EP, E214), Methyl Paraben (MP, E218), Propyl Paraben (PP, E216), Butylparaben (BP, E209) [1]. The molecular structures of some well-known parabens are shown in Figure 1. Different types of parabens are different in their functions and applications. Longer alkyl chain parabens have stronger effect on plant pathogenic fungi [2], and mixtures of the parabens show more effective of preservative than each individual paraben [3]. These parabens exist in some fruits and vegetables in nature, but most of them are synthesized from hydroxyl benzoic acid during industrial-scale process, and then modified for various types of our daily products. These synthetic methods have been developed over years with the reaction and procedure of simple principles. The key step is to improve the efficiency of manufacturing process, which is discussed in section 2 .

Parabens have been "safely" used in our daily life and are known as common preservatives in nature and commercial products. Parabens have little effect on bacterial spores, viruses, mycobacteria or prions [4] despite of its efficiency in preservation. Nature is smart and discovered these functions of parabens thousands of years ago. Parabens occur naturally in carrots, blueberries, olives, strawberries and mangoes, containing similar preservation properties as

*Address correspondence to this author at the Department of Chemical Science and Engineering, Royal Institute of Technology KTH, Stockholm, Sweden; E-mails: fanzhang@kth.se. Department of Chemical Engineering, University of College London; London; UK; London; Emails: han.wu@ucl.ac.uk synthetic parabens; helping them to defend themselves against various micro-organisms [5-7]. Human started to discover these functions of parabens about 100 years ago, which means that parabens are among the most welldocumented ingredients [8] in the market. The first use in pharmaceutical product reported can be found as early as 1920, where parabens were used as antimicrobial preservatives [9]. They were explored further in foodstuff, sorbitol solutions [10], vaccine [11] and cosmetics [12] in 1960 s, followed by a steady increase of the use in various food categories including vegetables, baked goods, fat and oils seasoning, sugar and coffee extracts, soft drinks and frozen dairy product at ppm level of concentrations [13]. By 2013, parabens were found to exist in all kinds of food products, such as bottled water, beers, formula milk, yogurts, wheat flour, bread, cakes, ham, sausages, apples, pears, cabbages [14].
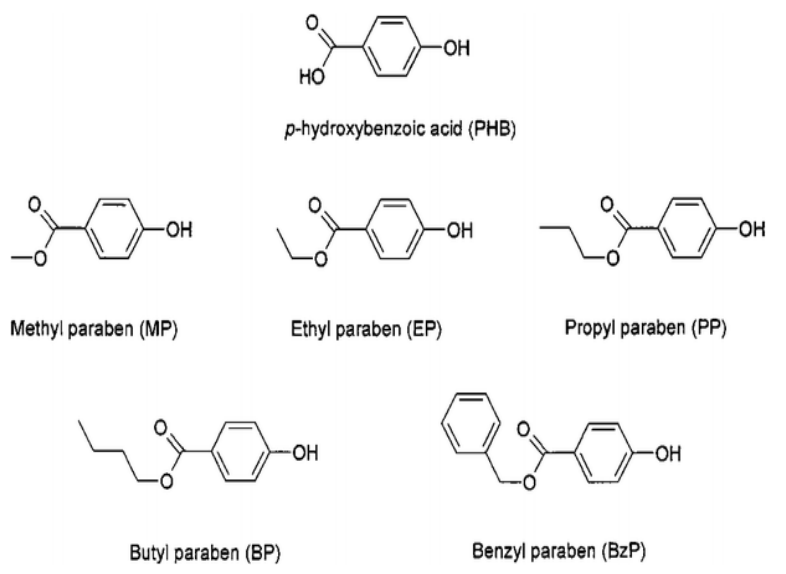

Figure 1 Molecular structures of PHB, MP, EP, PP, BP, and $\mathrm{BzP}[5]$ 


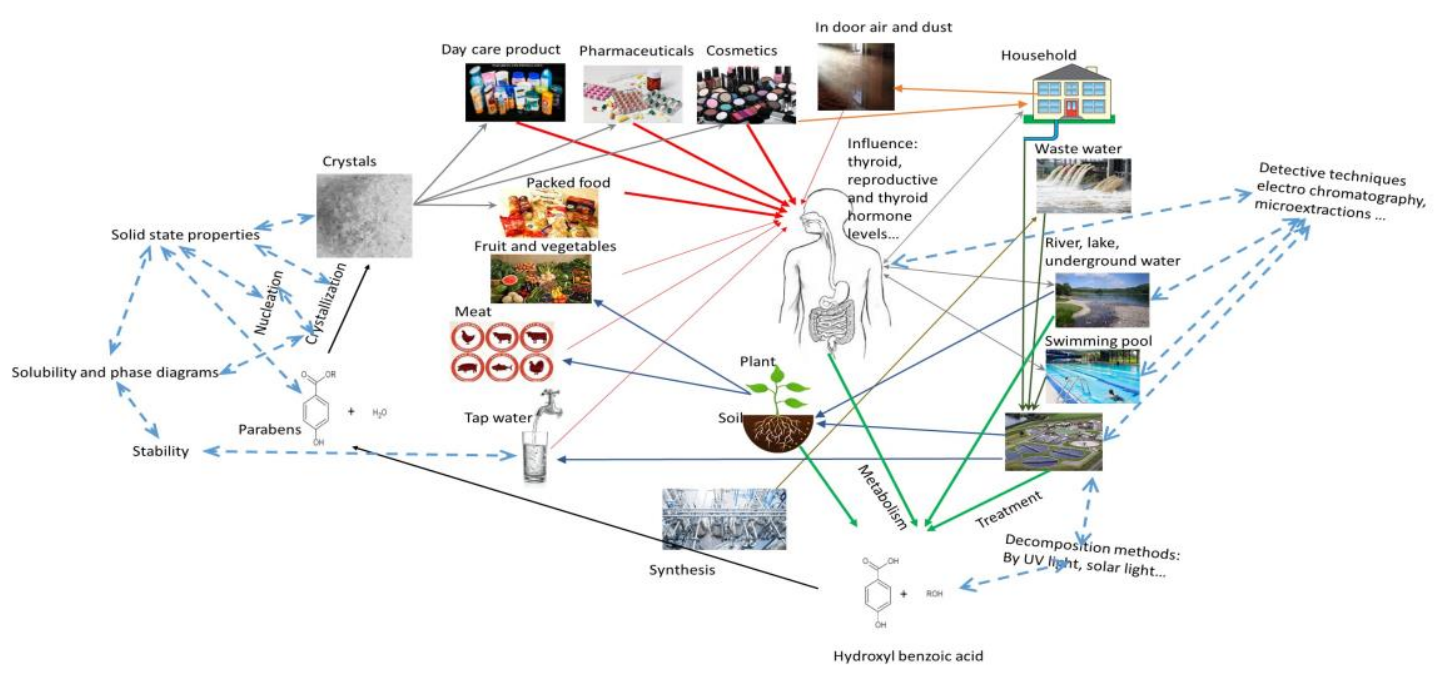

Figure 2 Life cycle of parabens

\section{LIFE CYCLE OF PARABENS}

Parabens are widely available in various forms, and their usages have been inevitably increased over several decades. In 1987, over $7000 \mathrm{~kg}$ of parabens were used in cosmetics and toiletries $[15-16,13]$, the usage continued to grow every year [14] due to their well preservative efficiency. Such massive usage has raised the worldwide concerns about their safety on human health. In order to understand the effect of parabens on human health, it is important to track the life cycle of parabens and understand how the parabens are produced, transformed, delivered, detected, and more importantly the various forms they exist. Furthermore, it is crucial to understand their structure-related properties such as chemical property, physical property, biochemical properties, and the difference in solid and liquid forms. All these should lead us to a better understanding of the safety concern and safety control of their usage in relevant industries and normal lives.

The life cycle of parabens is illustrated in Figure 2:

1). Parabens are firstly synthesized from preservative industry plant, purified by crystallization from solution. This step requires key knowledge on their solubility, phase diagrams, solvent-solute interactions and solid-state properties.

2). They are added into day care products, pharmaceuticals, packed food and cosmetics which are directly taken by human orally or via skin contact.

3). Some cosmetics will even release parabens to the atmosphere in the form of dust or air, leading to higher exposure via human activities.

4). The cosmetics and day care products taken by human may be released to rivers, lakes, underground water [17], swimming pool [18] and other surface water sources. Some may go inside the skin with water media, e.g. during swimming. Most of parabens, existing in surface water, household water and the waste water, can be decomposed during water treatments in reservoirs [19].

5). Some water containing parabens are irrigated, which means that the soils retain some parabens [20]. These parabens are absorbed by vegetables, food and fruit plants, before they were disgusted by cows, fish, chickens and other animals. Consequently, providing an indirect route for human intake as the food will be finally consumed by human.

6). Tap water may contain low levels of butyl paraben, providing another potential source for human intake.

7). The parabens taken by human, animals and in solid will eventually be decomposed or metabolized [21-22].

In summary, there are two cycles: i) parabens are 'born' (synthesized) from hydroxyl benzoic acid, and 'die' (be decomposed/be metabolized), forming hydroxyl benzoic acid compound again. ii) Human use/eat parabens, release parabens, and eventually some parabens can be taken back to human body in different ways. As a result, the increasing intakes of paraben in our daily life via complex pathways are hard to control [23].

\subsection{Synthesis of parabens}

parabens are widely 'synthesized' and 'utilised' as preservatives in nature, e.g. some plants can produce parabens to keep their fruit fresh; a microbulbifer bacterium produces parabens in its calcareous sponge [24]; a marine bacterium biosynthesizes parabens in preventing the growth of yeasts, molds, and gram-positive bacteria [1].

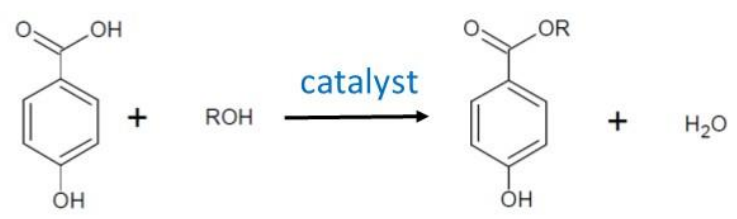

Figure 3 synthesis of parabens from p-hydroxyl benzoic acid. $\mathrm{R}$ represents $\mathrm{CH}_{3}, \mathrm{C}_{2} \mathrm{H}_{5}, \mathrm{C}_{3} \mathrm{H}_{7}, \mathrm{C}_{4} \mathrm{H}_{9}$.

The process to synthesize parabens in lab or industrial scale has been known for hundreds of years. It is a simple 'acid-base' reaction in the presence of a suitable catalyst [25] such as montmorillonite K10 clay [26], thionyl chloride [27], and dodeca tungstophosphoric acid [28]. Successful synthesis requires p-hydroxyl benzoic acid as the starting material, mixed with an appropriate amount of alcohol, and 
produce parabens as the main product and water as a byproduct, shown in Figure 3.

The traditional method is considered as a simple and robust process; while new technologies have been explored to improve the synthesis efficiency and cost-effectiveness by introducing microwave radiation and inorganic salt $\mathrm{ZnCl}_{2}$ as catalysts [25]. There is also a trend to develop more green methods as alternatives to save power and energy consumption during the manufacturing process [29].

\subsection{Decomposition pathways of parabens}

Another important aspect to look at the lifecycle of parabens is their decomposition pathways. Natural decomposition route via microorganisms is known where phenol and p-hydroxyl benzoic acid are formed [30-31]. Parabens consumed by human turn to p-hydroxyl benzoic acid too, and the conjugates are rapidly excreted in urine [15]. The purification process in wastewater treatment plant can effectively remove $90 \%$ of parabens, following biological treatments [32-33].

Table 1 Methods to degrade parabens

\begin{tabular}{|l|l|l|}
\hline UV light & With $\mathrm{H}_{2} \mathrm{O}_{2}$ under UV & {$[34]$} \\
\cline { 2 - 3 } & $\begin{array}{l}\text { With 0.1 M phosphate buffer } \\
\text { solutions under UV/ultrasound }\end{array}$ & {$[35]$} \\
\cline { 2 - 3 } & $\begin{array}{l}\text { Semiconductor photocatalysis } \\
\text { under UV light }\end{array}$ & {$[35]$} \\
\hline $\begin{array}{l}\text { Solar } \\
\text { radiation }\end{array}$ & $\begin{array}{l}\mathrm{TiO}_{2} \text { suspensions under } \\
\text { simulated solar radiation }\end{array}$ & {$[36]$} \\
\cline { 2 - 3 } & $\begin{array}{l}\text { With } \mathrm{TiO}_{2} \text { films deposited under } \\
\text { natural sunlight }\end{array}$ & {$[37-38]$} \\
\cline { 2 - 3 } & $\begin{array}{l}\text { ZnO photo catalyst under } \\
\text { simulated solar radiation }\end{array}$ & {$[39]$} \\
\hline Other & $\begin{array}{l}\text { Galvanostatic electrochemical } \\
\text { oxidation }\end{array}$ & {$[40]$} \\
\cline { 2 - 3 } & Biological treatment & {$[32-33]$} \\
\hline
\end{tabular}

Effective conversion methods can prevent contamination from environment by removing unwanted parabens residues. As shown in Table 1, various methods have been established over the years to eliminate parabens' residue including: i) by simulated solar radiation over $\mathrm{ZnO}$ photo catalyst [39]; ii) by $\mathrm{UV} / \mathrm{H} 2 \mathrm{O} 2$ [34] iii) by UV/ultrasound in $0.1 \mathrm{M}$ phosphate buffer solutions [35]; iv) by $\mathrm{TiO} 2$ suspensions under simulated solar radiation [36]; V) by galvanostatic electrochemical oxidation on a boron-doped diamond anode follows a first-order law [40]. One effective attempt is to remove parabens from aqueous solution with an hour, using $\mathrm{TiO}_{2}$ films deposited onto FTO/glass plates under natural sunlight [36-38]. A recent approach to reduce parabens by an optimised photosonolysis (US/UV) process showed higher removal rate was achieved compared to the conventional ultrasonication (US) and photochemical (UV) processes [35]. Apparently, there are always trace amount of parabens remaining in the environment or human body, despite of the discovery of these emerging techniques with the attempts to eliminate parabens completely from nature and commercial products. For example, parabens still exist in the surface water after purification treatment [41]. The existence of parabens residue in one source is arguably negligible, but the accumulation of the residues from various sources is enormous and must be taken care of carefully.

\section{CHARACTERIZATION OF PARABENS}

Effective detection and control of paraben usage can help us to better understand the life cycle of paraben, as explained in Figure 2. However, eliminating the intake of parabens is almost impossible due to their widespread sources, and accumulation from the environmental exposure [42]. Concerns have been raised on their safety and the potential impact on human health, which have been debated [43] for decades and controversies [44] still exist. For these reasons, an increasing number of researches have been carried out to characterise parabens via different methods since the 1950s, shown in Figure 4. Many researches reached the same conclusion that traces parabens are detectable in all kind of commercial products, while the attempt to quantify different types of parabens and their influences on human life/health are still challenging [43].

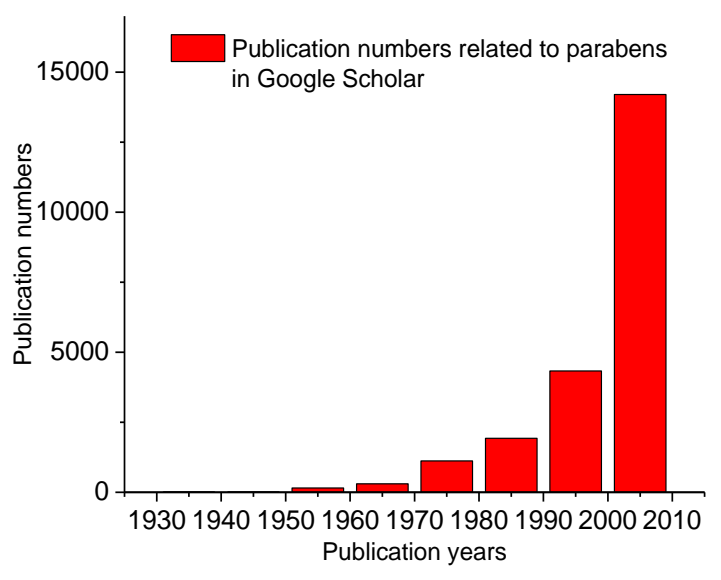

Figure 4 Publication statistics on research papers relating to parabens

Accurate assessments of the impact of parabens on the environment and human health require advanced analytical methods to monitor parabens residue inside the human tissues. Research articles on characterizing parabens are not rare; in fact, relevant studies have grown explosively and continuously in the past decades. This chapter prevents how parabens are analysed, characterised and quantified. The physical properties, such as solubility, melting point, polymorphism and morphologies were determined by DSC, TGA, FBRM, and PVM, and biophysical properties of parabens were studied in vivo and in vitro [45-46].

\subsection{Thermodynamic stability}

The thermodynamic stabilities of different parabens are demonstrated by their melting points, which can be directly determined by Differential Scanning Calorimetry measurement (DSC). The melting temperatures of parabens 
increase by decreasing molecular weights, which is affected by the size of the alkyl chain [47-49]:

$$
\begin{gathered}
\text { BP }\left(67.34{ }^{\circ} \mathrm{C}\right)<\operatorname{PP}\left(96.38{ }^{\circ} \mathrm{C}\right)<\operatorname{EP}\left(115.49^{\circ} \mathrm{C}\right)<\mathrm{MP} \\
\left(126.0{ }^{\circ} \mathrm{C}\right)
\end{gathered}
$$

However, the enthalpy of fusion doesn't follow the same order $[48,50]$ and the differences are relatively small,

$$
\begin{gathered}
\mathrm{MP}(25.333 \mathrm{~kJ} / \mathrm{mol})<\mathrm{BP}(25.535 \mathrm{~kJ} / \mathrm{mol})<\mathrm{EP}(25.761 \\
\mathrm{kJ} / \mathrm{mol})<\mathrm{PP}(26.507 \mathrm{~kJ} / \mathrm{mol})
\end{gathered}
$$

The melting point of $\mathrm{BzP}$ is about $110{ }^{\circ} \mathrm{C}$ [51] between melting points of PP and EP. Co-crystallization of MP with other molecules has been investigated by various groups: i) successful synthesis pharmaceutical co-crystal using MP and quinidine; ii) EP acts as "molecular hook" to separate quinidine from its stereoisomer quinine based hydrogenbond-mediated molecular recognition [52]; iii) nicotinamide increases the solubility of parabens [53] and co-crystal of 1:1 EP-nicotinamide [54] and BP-isonicotinamide [55], iv) single crystal X-ray analysis of parabens co-crystals revealed the formation of corrugated layers from conformers molecules, and associated hydrogen bonding network in the structures [54-55].

\subsection{Solubility analysis}

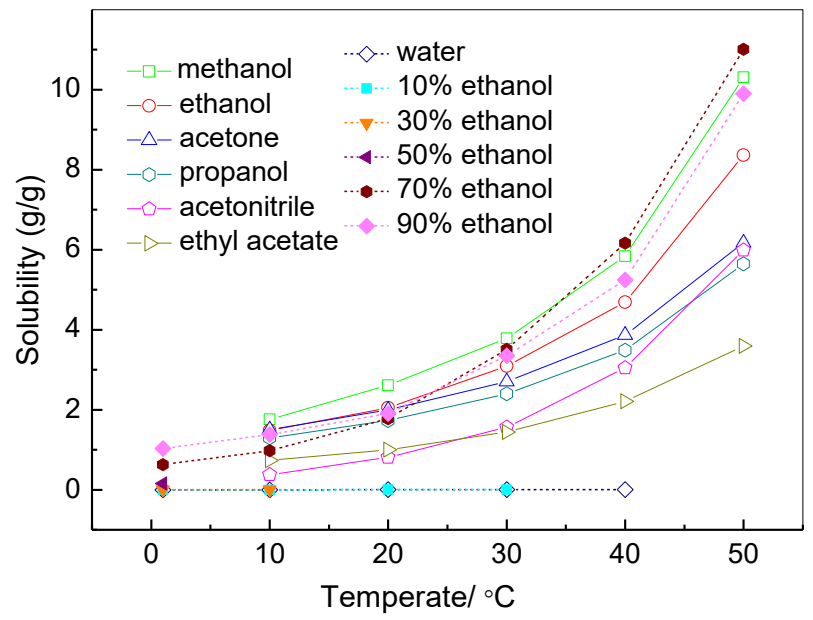

Figure 5 Solubility of BP in various solvents from $1.0^{\circ} \mathrm{C}$ to $50.0^{\circ} \mathrm{C}[56]$

Parabens are soluble in organic solvents [50, 57] (ethyl acetate, propanol, acetone, methanol, acetonitrile and ethanol) but insoluble in water [58-59]. Solubility of parabens in these solvents increases with increasing temperature, shown in Figure . At low temperature, e.g. at $10{ }^{\circ} \mathrm{C}$, solubility of BP is higher than PP and EP [50,60-62] in pure ethanol, and in aqueous solution with high proportions of ethanol. Solubility of BP is lower than PP and EP in water, and in 10\% ethanolwater mixture [50, 60-62]. PEG solid was reported to act as an enhancer for the dissolution [63] parabens, in the order of $\mathrm{BP}>\mathrm{PP} \sim \mathrm{EP}>\mathrm{MP}$ in aqueous solution [64]. The dissolution rate was affected by the diffusion mechanism, a dominating factor for the dissolution of MP and EP, followed by PP and BP [64].

Solubility of butyl paraben in 6 different organic solvents was compared in Figures 6, where $a-\Delta H^{f}$ (activity and enthalpy of fusion) curves and $x-\Delta H^{V H}$ (solubility and van der Hoff enthalpy) curves are both available in the same figure. The activity and activity coefficients $\left(\gamma_{e q}\right)$ in different solvents can be estimated from such analysis. It is clear that the activity coefficients in different solvents are hugely affected by the temperature: although the changes are anisotropic, the equilibrium value, $\gamma_{\mathrm{eq}} \gamma_{\mathrm{eq}}$ of $\mathrm{BP}$ tends to approach to $\gamma_{e q}=1$ while the temperature is close to the melting point, $340.49 \mathrm{~K}$ [47].

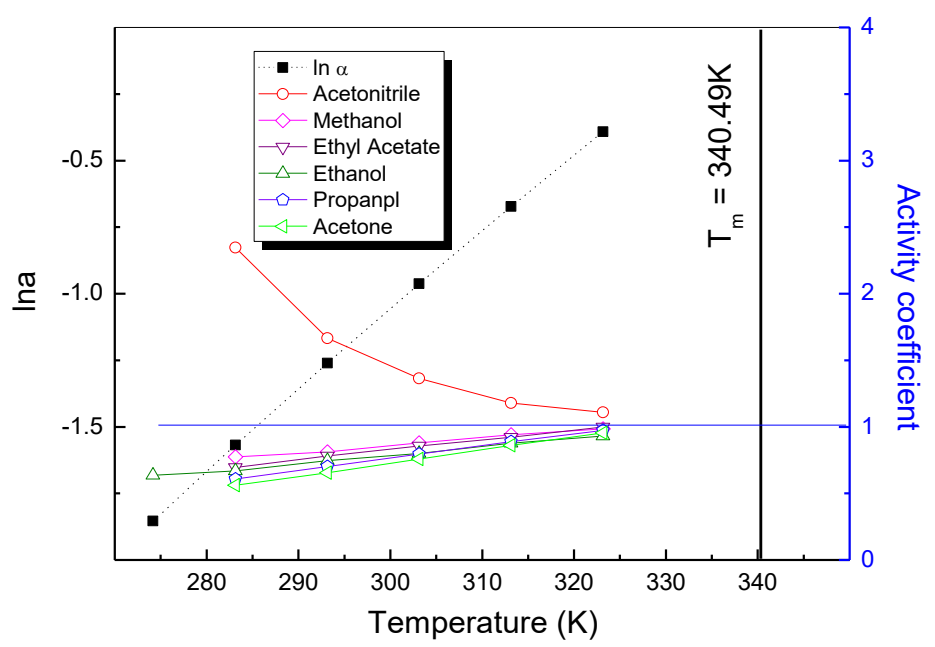

Figure 6 lna of butyl paraben and corresponding $\gamma_{e q}$ of butyl paraben in organic solvents [47]

\subsection{Solid-liquid interfacial properties}

Induction times of BP in ethanol were determined in crystallization platforms of multiply stirring vessels [65], stirring tank [66], moving fluid oscillatory baffled crystallizer [67] and Taylor- Couette flow system [65]. By classical nucleation theory [68-69], induction times at different levels of supersaturation are used to determine the solid liquid interfacial energy which is proportional to the slopes of the correlation lines [70-71]. Therefore, the higher of the slope in Figure is, the higher activation energy the nucleation requires and at equal driving force the longer induction time becomes.

The solid-liquid interfacial energies of parabens in these solvents are in the range of 0.3 to $2.4 \mathrm{~mJ} \cdot \mathrm{m}^{-2}$ [61,72-73], and the low interface energies of parabens indicate an easy nucleation and narrow metastable stable zone widths $[56,74-$ 75]. It was excepted that with longer alkyl chain, the arrangement and assembly of molecules before nucleation become more difficult, however the difficulty of nucleation increase with decrease of alkyl chain length. The interfacial energies increase with increase in melting points of parabens in same solvent, and increase with increase in boiling points of solvents for each paraben shown in Figure 7. This is due to the nucleation is highly correlated to the intermolecular and intramolecular force between solute, solvent and each other [73]. For a simple explanation, if one system is composed with higher melting point solute and higher boiling point solvent, the molecules are more averse to form new interfaces between nuclei with liquid phase. The kinetics also plays an important role in nucleation behaviours, higher shear rates lead to a decrease in induction times. However, the induction times have a minimum value and then increases above this 'critical value' with further increase in the shear rates $[73,65]$. 

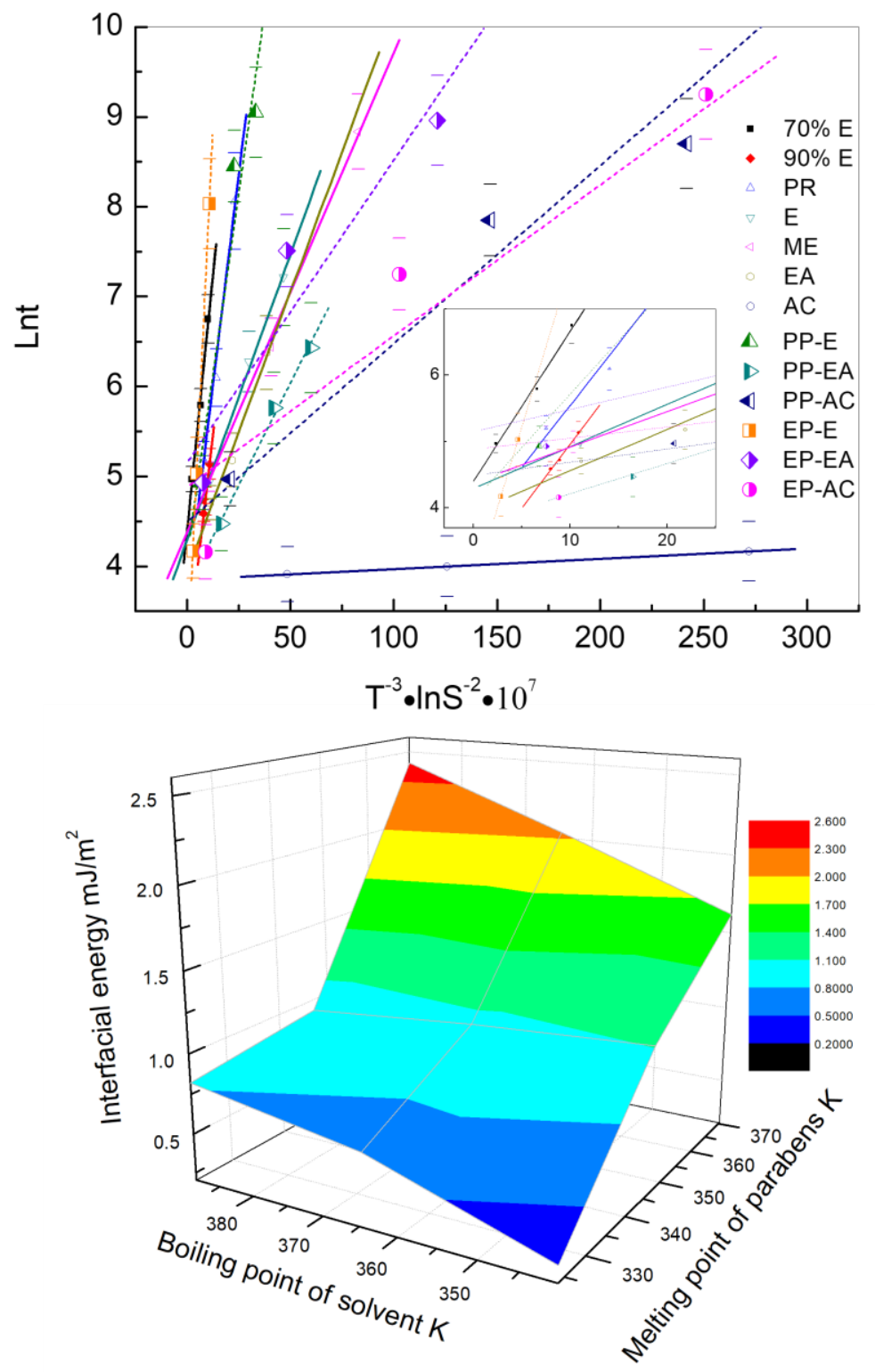

Figure 7 Top: lnt of BP, PP, EP in 70\% ethanol, 90\% ethanol, propanol, methanol versus $T^{-3}(\ln S)^{-2}$ with first order correlation lines [72-73]. Bars indicate the 95\% confidence interval of lnt. Bottom: Relation of solid liquid interfacial energy with melting points of parabens and boiling points of solvents [73].

\subsection{Ternary phase diagrams and crystallization methods}

There are five regions in ternary diagrams of parabens water and ethanol in Figure 8 [61]. Region 1 and 2 are undersaturated (with respect to paraben) homogeneous liquid and liquid-liquid phases, respectively. Region 3, 4 and 5 are saturated solid-liquid phase (low concentration BP), liquidliquid solid phase and another solid-liquid phase (high concentration BP), respectively [60-62]. Formation of liquidliquid phase separation (LLPS) mainly is because hydrophobic alkyl chain of paraben associated with ethanol resists water associated with ethanol. LLPS region expands gradually into the ethanol lean part of the diagram at higher temperature or with longer alkyl chains for these parabens, respectively [62].

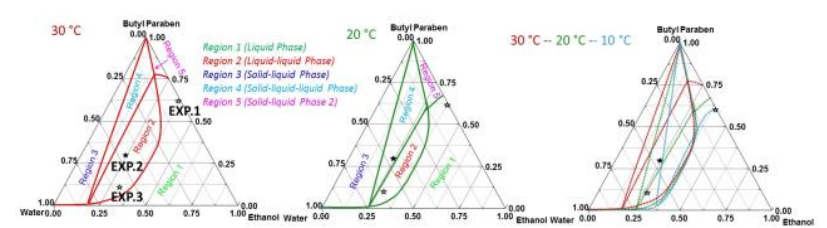

Figure 8 Ternary phase diagrams of butyl paraben, water and ethanol [56] and composing points of solution in three cooling experiments, Exp. 1, Exp.2 and Exp. 3 [61-62, 76].

Exp. 1 was an ordinary cooling crystallization in a homogenous solvent from region 1 to region 5 in Figure 8, and the normal single crystals formed (offline images in Figure 9). Focused Beam Reflectance Measurement (FBRM) curves show no particles or droplets before nucleation. The solutions of Exp. 2 and 3 started more or less in LLPS region 2 , at cooling the solution remained milk-white, the formation of droplets was observed by the Particle Vision and Measurement (PVM) and FBRM (not equal to zero). Jump of FBRM curves indicates nucleation across the phase boundary between region 4 and region 2, however, FBRM curves in Exp. 3 decrease due to a higher re-dissolution rate of the droplets (Figure 9) then forming rate of crystals. The process of both Exp. 2 and Exp. 3 ended in region 3 where solid BP crystals grew in homogeneous solution. However, crystals were heavily agglomerated in Exp.3 and crystals with a novel sandwich structure were obtained in Exp. 2 [56, 77]. The crystallization processes in LLPS solution of parabens are dependent on the compositions in ternary diagram, i.e. how the solutions go across phase boundary lines. In these cooling crystallization experiments, the composition points remain, but the phases' boundaries shifts, and in evaporation crystallization experiments at the same temperature, the composition points move toward to top BP point in the same ternary phase diagram.

\subsection{Crystal structures and polymorphism}

Polymorphism [78] is common phenomena and exists in wide range of organic compounds, especially those used in pharmaceutical industry. New polymorphs with different crystal structures are often discovered by changing the temperature or other environmental conditions. A new polymorph of MP was captured at $118 \mathrm{~K}$ in 2006 [79], while later examination of the two polymorphs proved that their structures were identical. The conformational differences seen at $118 \mathrm{~K}$ appeared to be within reasonable lattice changes due to the thermal expansion [80]. Polymorph II was finally reported and confirmed in 2011 [81], followed by the discovery more MP polymorphs. Four polymorphs of MP were characterized and compared in 2013, showing distinct crystal structures and lattice energy [82]. Other parabens are less polymorphic, till now only one polymorph was reported for EP, PP and BP [49, 73, 83].

The crystal structure and molecule structure of EP, MP and BP are very similar, as shown in Figure 10 [84]. Parabens crystals grown from the same organic solvent (ethanol, ethyl acetate, or acetone) had similar morphology 


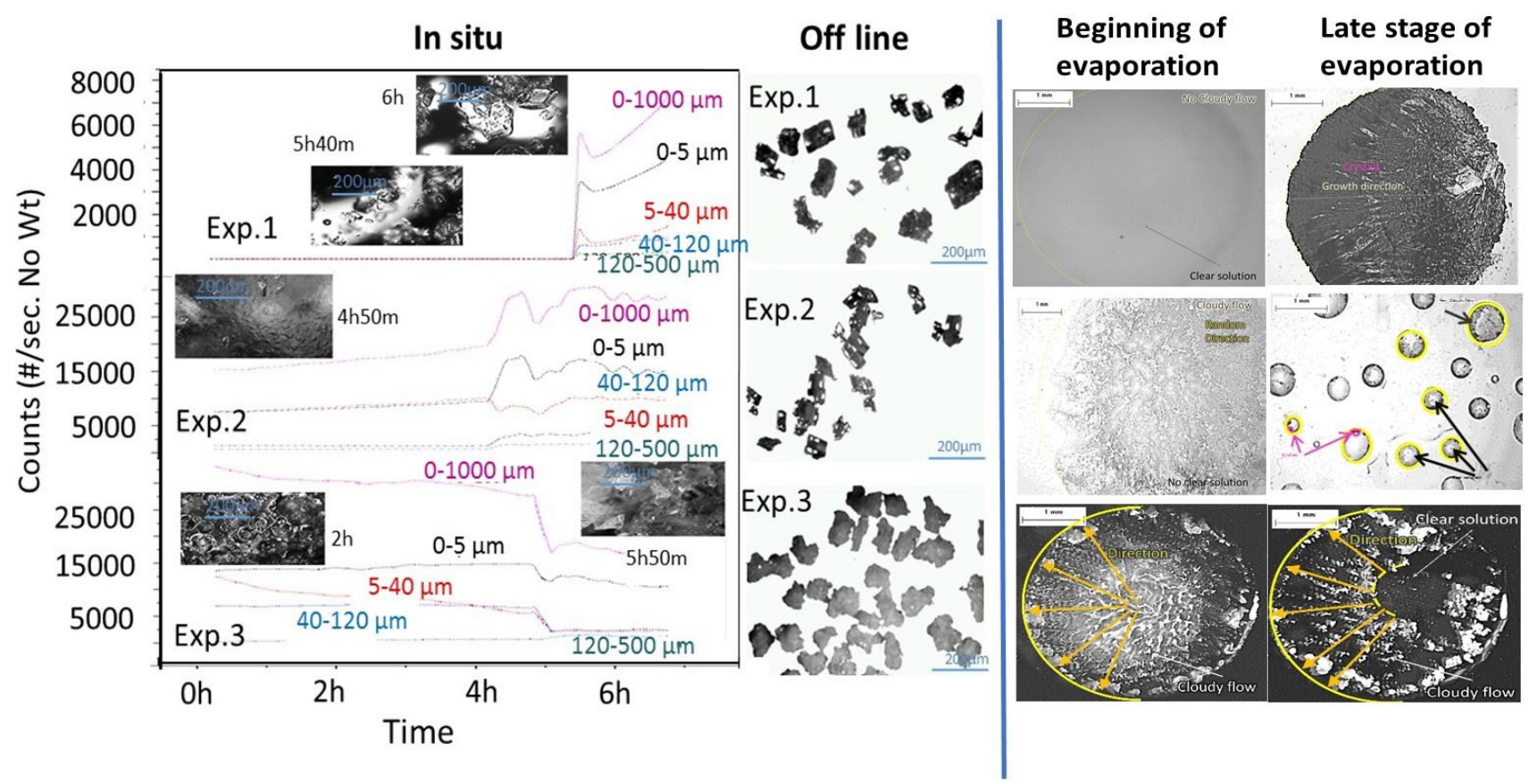

Figure 9 FBRM curves of Exp .1 to Exp. 3 with in-situ PVM photos in cooling crystallization process and off-line microscope images of product crystals [61-62, 76]

which were consistent with computational simulation using BFDH method [85]. The solvent effect on the crystal interfacial energy was strong, while the crystal morphology change caused by solvent is not so obvious.

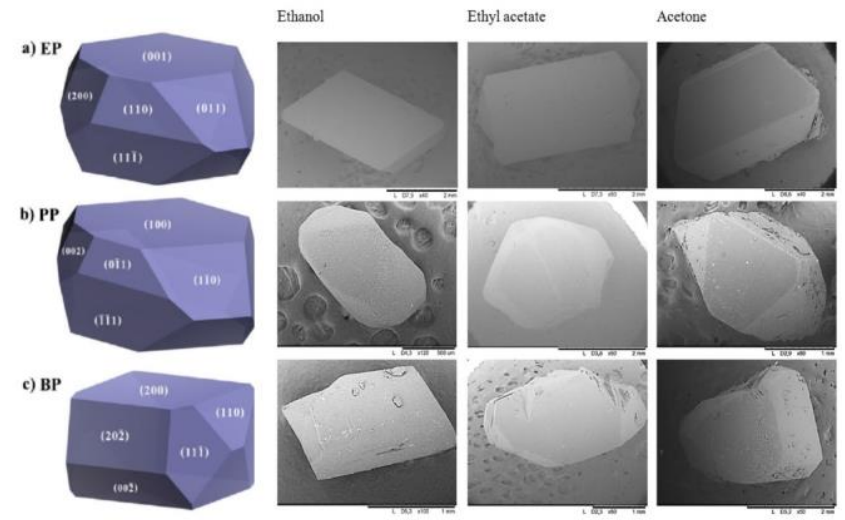

Figure 10 Left: Predicted morphologies of a) EP, b) PP and c) BP and SEM images of grown by slow evaporation in ethanol, ethyl acetate and acetone [72-73].

A unique crystal structure was obtained in Exp. 2 [77]. The crystals had a characteristic layer in the middle of each crystal, parallel to the basal planes (Figure 11). The top and bottom layers are transparent and compact. The middle layer was porous (not transparent), with the pore size ranging from several $\mu \mathrm{ms}$ to dozens of $\mathrm{nm}$, and with thickness $>50 \%$ the whole crystals. The IR and confocal Raman spectroscopic studies indicated that the 'polymorphs' from three layers of the sandwich crystal are actually the same [77], which was in a good agreement with data obtained from X-ray Powder Diffraction analysis (XRPD) [73, 86], Differential Scanning Calorimetry (DSC) and hot stage microscope. The methods to identify crystal structure or polymorph were not limited to the above examples. Other reported technologies includes thermal gravimetric analysis (TGA) [87], nuclear magnetic resonance (NMR) [86], ultraviolet Spectrophotometer (US) [88], and Atomic-force microscopy (AFM) [89-95], together with other technologies listed in Table 2.

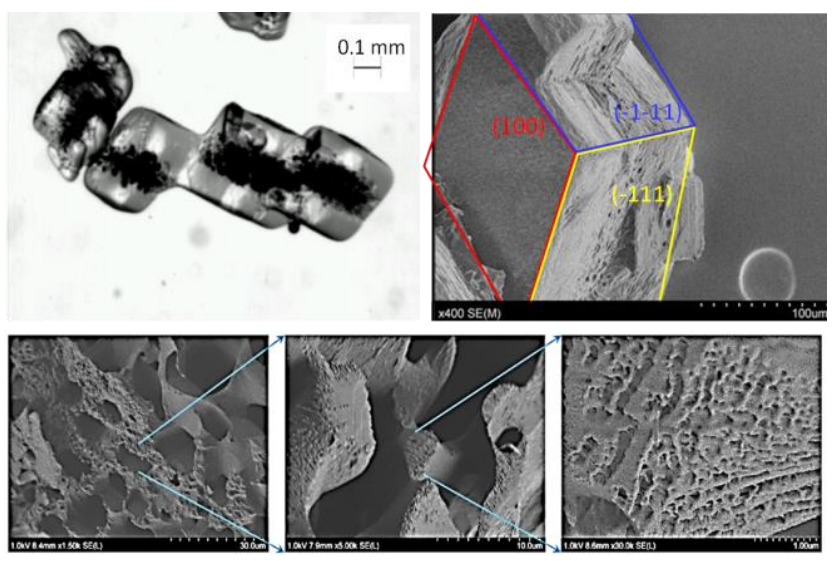

Figure 11 Microscope and SEM images of BP sandwich crystals and the pores inside crystals $[56,77]$

Table 2 Solid-state characterization techniques

\begin{tabular}{|c|c|}
\hline $\begin{array}{c}\text { Shape and } \\
\text { surface }\end{array}$ & $\begin{array}{c}\text { Optical Microscope, SEM, AFM, PVM, } \\
\text { hot stage microscope }\end{array}$ \\
\hline $\begin{array}{c}\text { Structure and } \\
\text { polymorphism }\end{array}$ & $\begin{array}{c}\text { Single crystal XRD, XRPD, NMR, Mass } \\
\text { Spectrometry (MS), near infrared, FTIR }\end{array}$ \\
\hline $\begin{array}{c}\text { Thermodynamic } \\
\text { stability }\end{array}$ & TGA, DSC, Dynamic Vapor Sorption (DVS) \\
\hline $\begin{array}{c}\text { Particles } \\
\text { size/number }\end{array}$ & $\begin{array}{c}\text { Focused Beam Reflectance Measurement } \\
\text { (FBRM), Dynamic Light Scattering (DLS), }\end{array}$ \\
\hline Concentration & $\begin{array}{c}\text { Ultraviolet Spectrophotometer (US), } \\
\text { Raman, FTIR, HPLC }\end{array}$ \\
\hline
\end{tabular}




\section{DETECTION AND MONITORING OF PARABENS}

Parabens are around human's normal life, appearing in urine samples [14] of more than $90 \%$ of the U.S. general population of children [96], male and female [97], where parabens are detected with concentrations with order of several tens $\mathrm{ng} / \mathrm{mL}$ [97]. Widely and huge amount use of parabens has many foot prints in the nature world shown in Table 3. Parabens were detected in fish tissue [98], the methyl paraben existed in roots [99] of herbaceous plant [100]. Parabens were present in some mushroom species [101] and unifloral honeys [102]. Parabens existed 0.45-6.4 $\mathrm{ng} / \mathrm{g}$ in forestry and agricultural soils and sediments from different areas [103] and $1.22-2.92 \mathrm{~g} / \mathrm{ml}$ in sewage [104] of Spain, up to $1.47-2.47 \mathrm{~g} / \mathrm{mL}$ in all sewage in Canada [105], 6.87 to $1029 \mathrm{ng} / \mathrm{L}$ in urban surface water [106] and about 8 $\mathrm{mg} / \mathrm{L}$ in swimming pools in Beijing, China [18], 0.2-400 $\mathrm{ng} / \mathrm{L}$ in surface water in South wales [107], in 1.2-17.3ng/L in surface water in Galicia Spain [108], 0.2-17 ng/L in Switzerland [41], 2.4-147 ng/L in South India [109], 2.1-25 $\mathrm{ng} / \mathrm{L}$ in Central pacific region of Japan [110], 2.2-17.3 ng/L in Greater Pittsburgh area [111], 0.2-64 ng/L in Ria de Aveiro are Portugal [112]. Over all, the surface water in the worldwide was very low in the scale of ng scale, and the water in swimming pool and in sewage is usually hundreds of times higher than the concentration in the surface water.

Table 3 Paraben concentration in Surface water worldwide

\begin{tabular}{|l|l|l|}
\hline Surface water & Location & Ref. \\
\hline $0.2-400 \mathrm{ng} / \mathrm{L}$, & South wales & {$[96]$} \\
\hline 6.87 to $1029 \mathrm{ng} / \mathrm{L}$ & Beijing & {$[97]$} \\
\hline $0.2-64 \mathrm{ng} / \mathrm{L}$ & Ria de Aveiro, Portugal & {$[98]$} \\
\hline $1.2-17.3 \mathrm{ng} / \mathrm{L}$ & Galicia Spain, & {$[99]$} \\
\hline $0.2-17 \mathrm{ng} / \mathrm{L}$ & Switzerland & {$[41]$} \\
\hline $2.1-25 \mathrm{ng} / \mathrm{L}$ & Central pacific region of Japan & {$[100]$} \\
\hline $2.4-147 \mathrm{ng} / \mathrm{L}$ & South India & {$[101]$} \\
\hline $2.2-17.3 \mathrm{ng} / \mathrm{L}$ & Greater Pittsburgh area, USA & {$[102]$} \\
\hline
\end{tabular}

To detect the concentration, various techniques for parabens detection can be applied, such as high performance liquid chromatography [103], an improved thin layer chromatography HPTLC [104], gas chromatography [105] and flow injection system combined with chemiluminescence [106]. These techniques have high accuracy with low detection limits, but they are relatively expensive [107] and time-consuming [108]. Several techniques on nanostructured electrodes [109] and electrochemical sensors [110] based on a thin film electrode consisting of synthesized Ln2O3 nanobricks coated on glassy carbon electrode (GCE) for the detection of trace amounts of BP have been developed [107]. Alternative new detective methods includes galvanostatic electrochemical oxidation on a boron-doped diamond anode [111], and capillary electro chromatography [112] to achieve $0.3 \mathrm{nM}$ measurement limits of detection by using differential pulse voltammetry for propyl paraben [113]. For more accurate detection and evaluate the influence of parabens around human normal lives, effective extraction techniques [114] were developed, like solid-phase microextraction (SPME) [115], liquid-phase microextraction (LPME) [116], microwave-assisted extraction (MAE) [117], ultrasoundassisted extraction (UAE) [118] and supercritical fluid extraction (SFE) [119]. Some novel solid phase extraction technologies like multi-walled carbon nanotube [120] and molecularly imprinted polymer [121] as the sorbents becomes more and more popular [122]. Combination of extraction method with detection method need to be developed for efficiency, for example electro-membrane extraction [123] method can be coupled to flow injection analysis - chemiluminescence [124].

\section{SAFE OR NOT SAFE TO USE PARABENS?}

There is a growing concern with parabens, as they have been shown to disrupt hormone function and destructive to human health [125]. Parabens can penetrate into the human circulatory system from a single topical cosmetic application to a human subject [126], therefore a higher risk of the oestrogen equivalents a paraben-containing lotion [127]. Parabens are shown in fetal blood, easily crossing the uteroplacental barrier. Parabens are found in in urine, serum, seminal plasma [22] and transplacental [128]. Exposure to parabens shortens menstrual cycle length [129]. Parabens are classified as endocrine disruptors, which are associated with breast tumors [130] and male reproductive system [125] [130]. Parabens caused decrease of some thyroid level [126, $131,17,132]$, and weaken genetic stability [133], which instability of the genome in human cells is an important contributor to genetic changes that drive tumorigenic processes [134]. Parabens influence DNA and transactivation of gene expression [135-136]. Parabens decrease the expressions of some proteins and accumulated on the skin [137]. Parabens show ability to induce oestrogenregulated gene expression, MP and EP showed generally lower oestrogenic activity than did PP, BP and BzP [138139], and then progress to the question of whether physiological responses can be induced in cells in culture [140-141]. Not only parabens, but their metabolic hydrolysis and common metabolite, p-hydroxybenzoic acid acts to eradicate oestrogenic body burdens[138].

Table 4 Safe or risk for using parabens

\begin{tabular}{|l|l|l|}
\hline No influence on & \multicolumn{2}{|l|}{ Evidence for a risk, influence on } \\
\hline $\begin{array}{l}\text { Dental alveolitis } \\
{[142]}\end{array}$ & $\begin{array}{l}\text { Hormone } \\
\text { function } \\
{[125]}\end{array}$ & $\begin{array}{l}\text { Menstrual cycle } \\
\text { length [129] }\end{array}$ \\
\hline $\begin{array}{l}\text { Reactions on skin } \\
\text { sensitization [13] }\end{array}$ & $\begin{array}{l}\text { Oestrogen } \\
\text { balance } \\
{[127]}\end{array}$ & $\begin{array}{l}\text { Genetic stability } \\
{[133] \text { [134] }}\end{array}$ \\
\hline $\begin{array}{l}\text { Development and } \\
\text { microbial } \\
\text { composition of biofilm } \\
\text { periphyton } \\
{[143]}\end{array}$ & $\begin{array}{l}\text { Endocrine } \\
\text { disruptors } \\
{[130]}\end{array}$ & $\begin{array}{l}\text { DNA } \\
\text { transactivation of and } \\
\text { gene expression } \\
{[135-136] .}\end{array}$ \\
\hline $\begin{array}{l}\text { Short- and long-term } \\
\text { toxicological } \\
\text { consequences in } \\
\text { animals [15] }\end{array}$ & $\begin{array}{l}\text { Thyroid level } \\
{[126, \quad 131,} \\
17,132]\end{array}$ & $\begin{array}{l}\text { Expressions of } \\
\text { some proteins on } \\
\text { the skin [137] }\end{array}$ \\
\hline
\end{tabular}

However, many researches reported no significant influence or no influence of exposure to parabens [144]. Most of the parabens inside body were hydrolyzed to p-hydroxybenzoic acid, conjugated, and the conjugates were rapidly excreted in the urine, without evidence of accumulation [15]. Skin sensitization did not show reactions with $0.1-0.3 \%$ in 
topical medicaments test in 3455 human subjects [13]. No correlations were found between paraben concentrations and age of patient (37-91 years old), length of breast feeding ( 0 23 months), tumour location or tumour oestrogen receptor content [145]. Parabens prevented dental alveolitis compare placebo by experiment [125]. There were no short-term toxicological consequences in rat, rabbit, cat, dog or man and no long-term toxicological consequences in rats, following consumption of the parabens in amounts greatly exceeding those currently consumed in the normal diet of US population [15]. No effect of inject large did intrathecally or perineurally on long-last neural blockade or histologic evidence of damage [146]. The development and microbial composition of periphyton biofilm were not affected by parabens at environmental relevant concentrations under a 32 days' continuous exposure scenario [131]. No potential health effects [147] were reported about exposure to occupational parabens. Evidence of significant influences of parabens might be insufficient [13, 145], parabens are still safe to remain on the market, and may not need a significant environmental concern [146]. But with such widespread presence of parabens in urines across the population, there is a need to equally understand distribution in all body tissues [138]. It is important to efficiently control the human intake from multiply resources and accurately assess the effects of widespread presence of parabens in the environment and organisms.

\section{CONCLUSION}

Parabens, commercial preservatives in pharmaceuticals, food, day care products and cosmetics have been on the market for nearly 100 years. Parabens are usually synthesized from hydroxyl benzoic acid and new synthesis methods are being developed for cost-effective manufacturing to meet the growing demand. There has been a growing concern over the safe usage/disposal of parabens due to the increasing production and the accumulations of parabens from solid, water, air, fruit and animals. For the concerns, advanced characterization methods have been developed and applied to accurately detect and monitor parabens accumulations from the environments and human activities. The physical, biophysical and chemical properties of parabens were tested and characterized by a set of complimentary techniques. The evidences of their potential damages to human health were investigated and correlated to their influence on oestrogen balance and genetic stability. However, the safety of parabens is still debatable, and control of the parabens' intake becomes essential. It's undoubtedly important to measure and trace the usages of parabens accurately, for the effective evaluation of the safety level and safety control of parabens. Therefore, it is very important to understand the life cycle of parabens. Undoubtedly the investigations, disputations and arguments around parabens will continue, but parabens continue to exist in our world for long time.

\section{CONFLICT OF INTEREST}

There is no conflict of interest.

\section{REFERENCES}

[1.] Peng, X.; Adachi, K.; Chen, C.; Kasai, H.; Kanoh, K.; Shizuri, Y.; Misawa, N., Discovery of a marine bacterium producing 4-hydroxybenzoate and its alkyl esters, parabens. Applied and environmental microbiology 2006, 72 (8), 5556-5561.

[2.] Ito, S.; Yazawa, S.; Nakagawa, Y.; Sasaki, Y.; Yajima, S., Effects of alkyl parabens on plant pathogenic fungi. Bioorganic \& medicinal chemistry letters 2015, 25 (8), 1774-1777.

[3.] Littlejohn, O. M.; Husa, W. J., The potentizing effect of antimolding agents in syrups. Journal of the American Pharmaceutical Association (Scientific ed.) 1955, 44 (5), 305-308.

[4.] Haman, C.; Dauchy, X.; Rosin, C.; Munoz, J.-F., Occurrence, fate and behavior of parabens in aquatic environments: a review. Water research 2015, 68, 1-11.

[5.] Michalkiewicz, S., Anodic oxidation of parabens in acetic acid-acetonitrile solutions. Journal of Applied Electrochemistry 2013, 43 (1), 85-97.

[6.] Kang, Y.-H.; Parker, C. C.; Smith, A. C.; Waldron, K. W., Characterization and distribution of phenolics in carrot cell walls. Journal of agricultural and food chemistry 2008, 56 (18), 8558-8564.

[7.] Sellappan, S.; Akoh, C. C.; Krewer, G., Phenolic compounds and antioxidant capacity of Georgia-grown blueberries and blackberries. Journal of Agricultural and Food Chemistry 2002, 50 (8), 2432-2438.

[8.] Gruvberger, B.; Bruze, M.; Tammela, M., Preservatives in moisturizers on the Swedish market. ACTA DERMATOVENEREOLOGICA-STOCKHOLM- 1998, 78, 52-56.

[9.] Sabalitschka, T.; Neumann, G., Analysenganges von der Ammonsulfidfällung an bei Gegenwart von Phos phorsäure neben Erdalkalien und dergl. Fresenius' Journal of Analytical Chemistry 1930, 79 (10), 402-403.

[10.] Barr, M.; Tice, L. F., The preservation of aqueous sorbitol solutions. Journal of the American Pharmaceutical Association 1957, 46 (4), 221-223.

[11.] Goldblum, N.; Gotlieb, T.; Miller, G., Production of formalinized poliomyelitis vaccine (Salk-type) on a semiindustrial scale. Bulletin of the World Health Organization 1957, 17 (6), 1001.

[12.] Barr, M.; Tice, L. F., The preservation of aqueous preparations containing nonionic surfactants II. Preservative studies in solutions and products containing nonionic surfactants. Journal of the American Pharmaceutical Association 1957, 46 (7), 445-451.

[13.] Soni, M.; Carabin, I.; Burdock, G., Safety assessment of esters of p-hydroxybenzoic acid (parabens). FOOD CHEM TOXICOL 2005, 43 (7), 985-1015.

[14.] Liao, C.; Liu, F.; Kannan, K., Occurrence of and dietary exposure to parabens in foodstuffs from the United States. Environmental science \& technology 2013, 47 (8), 3918-3925.

[15.] Soni, M.; Taylor, S. L.; Greenberg, N.; Burdock, G., Evaluation of the health aspects of methyl paraben: a review of the published literature. FOOD CHEM TOXICOL 2002, 40 (10), 1335-1373.

[16.] Soni, M.; Burdock, G.; Taylor, S.; Greenberg, N., Safety assessment of propyl paraben: a review of the 
published literature. FOOD CHEM TOXICOL 2001, 39 (6), 513-532.

[17.] Błędzka, D.; Gromadzińska, J.; Wąsowicz, W., Parabens. From environmental studies to human health. Environment international 2014, 67, 27-42.

[18.] Li, W.; Shi, Y.; Gao, L.; Liu, J.; Cai, Y., Occurrence and human exposure of parabens and their chlorinated derivatives in swimming pools. Environmental Science and Pollution Research 2015, 22 (22), 17987-17997. [19.] Albero, B.; Pérez, R. A.; Sánchez-Brunete, C.; Tadeo, J. L., Occurrence and analysis of parabens in municipal sewage sludge from wastewater treatment plants in Madrid (Spain). Journal of hazardous materials 2012, 239, 48-55.

[20.] Ferreira, A. M. C.; Möder, M.; Laespada, M. F., Stir bar sorptive extraction of parabens, triclosan and methyl triclosan from soil, sediment and sludge with in situ derivatization and determination by gas chromatographymass spectrometry. Journal of Chromatography A 2011, 1218 (25), 3837-3844.

[21.] Khan, S. R.; Glenton, P. A.; Talham, D. R., Presence of lipids in urine, crystals and stones: implications for the formation of kidney stones. Kidney international 2002, 62 (6), 2062-2072.

[22.] Frederiksen, H.; Jørgensen, N.; Andersson, A.-M., Parabens in urine, serum and seminal plasma from healthy Danish men determined by liquid chromatography-tandem mass spectrometry (LC-MS/MS). Journal of Exposure Science and Environmental Epidemiology 2011, 21 (3), 262271.

[23.] Asimakopoulos, A. G.; Thomaidis, N. S.; Kannan, K., Widespread occurrence of bisphenol A diglycidyl ethers, p-hydroxybenzoic acid esters (parabens), benzophenone type-UV filters, triclosan, and triclocarban in human urine from Athens, Greece. Science of the Total Environment 2014, 470, 1243-1249.

[24.] Quévrain, E.; Domart - Coulon, I.; Pernice, M.; Bourguet - Kondracki, M. L., Novel natural parabens produced by a Microbulbifer bacterium in its calcareous sponge host Leuconia nivea. Environmental microbiology 2009, 11 (6), 1527-1539.

[25.] Liao, X.; Raghavan, G.; Yaylayan, V., A novel way to prepare n-butylparaben under microwave irradiation. Tetrahedron letters 2002, 43 (1), 45-48.

[26.] Hazarika, M. K.; Parajuli, R.; Phukan, P., Synthesis of parabens using montmorillonite K10 clay as catalyst: A green protocol. Indian journal of chemical technology 2007, 14 (1), 104.

[27.] Hosangadi, B. D.; Dave, R. H., An efficient general method for esterification of aromatic carboxylic acids. Tetrahedron letters 1996, 37 (35), 6375-6378.

[28.] Chungen, S. X. L., Synthesis of Butyl p Hydroxybenzoate with Dodecatungstophosphoric Acid Catalyst [J]. JOURNAL OF JIANGXI NORMAL UNIVERSITY (NATURAL SCIENCES EDITION) 1998, 4.

[29.] Yang, L., Research Progress on the Green Synthesis of Paraben [J]. Anhui Chemical Industry 2013, 2, 004.

[30.] Close, J.-A.; Neilsen, P., Resistance of a strain of Pseudomonas cepacia to esters of p-hydroxybenzoic acid. Applied and environmental microbiology 1976, 31 (5), 718722.
[31.] Valkova, N.; Lépine, F.; Valeanu, L.; Dupont, M.; Labrie, L.; Bisaillon, J.-G.; Beaudet, R.; Shareck, F.; Villemur, R., Hydrolysis of 4-hydroxybenzoic acid esters (parabens) and their aerobic transformation into phenol by the resistant Enterobacter cloacae strain EM. Applied and environmental microbiology 2001, 67 (6), 2404-2409.

[32.] Andersen, H. R.; Lundsbye, M.; Wedel, H.; Eriksson, E.; Ledin, A., Estrogenic personal care products in a greywater reuse system. Water Science and Technology 2007, 56 (12), 45-49.

[33.] Tay, K. S.; Rahman, N. A.; Abas, M. R. B., Ozonation of parabens in aqueous solution: Kinetics and mechanism of degradation. Chemosphere 2010, 81 (11), 1446-1453.

[34.] Sánchez-Martín, J.; Beltrán-Heredia, J.; Domínguez, J., Advanced photochemical degradation of emerging pollutants: methylparaben. Water, Air, \& Soil Pollution 2013, 224 (5), 1-12.

[35.] Daghrir, R.; Dimboukou-Mpira, A.; Seyhi, B.; Drogui, P., Photosonochemical degradation of butylparaben: Optimization, toxicity and kinetic studies. Science of the Total Environment 2014, 490, 223-234.

[36.] Velegraki, T.; Hapeshi, E.; Fatta-Kassinos, D.; Poulios, I., Solar-induced heterogeneous photocatalytic degradation of methyl-paraben. Applied Catalysis B: Environmental 2015, 178, 2-11.

[37.] Petala, A.; Frontistis, Z.; Antonopoulou, M.; Konstantinou, I.; Kondarides, D. I.; Mantzavinos, D., Kinetics of ethyl paraben degradation by simulated solar radiation in the presence of $\mathrm{N}$-doped TiO 2 catalysts. Water research 2015, 81, 157-166.

[38.] Neumann-Spallart, M.; Shinde, S.; Mahadik, M.; Bhosale, C., Photoelectrochemical degradation of selected aromatic molecules. Electrochimica Acta 2013, 111, 830836.

[39.] Frontistis, Z.; Antonopoulou, M.; Venieri, D.; Dailianis, S.; Konstantinou, I.; Mantzavinos, D., Solar photocatalytic decomposition of ethyl paraben in zinc oxide suspensions. Catalysis Today 2016.

[40.] Steter, J. R.; Rocha, R. S.; Dionísio, D.; Lanza, M. R.; Motheo, A. J., Electrochemical oxidation route of methyl paraben on a boron-doped diamond anode. Electrochimica Acta 2014, 117, 127-133.

[41.] Jonkers, N.; Kohler, H.-P. E.; Dammshäuser, A.; Giger, W., Mass flows of endocrine disruptors in the Glatt River during varying weather conditions. Environmental pollution 2009, 157 (3), 714-723.

[42.] Xue, J.; Sasaki, N.; Elangovan, M.; Diamond, G.; Kannan, K., Elevated Accumulation of Parabens and their Metabolites in Marine Mammals from the United States Coastal Waters. Environmental science \& technology 2015, 49 (20), 12071-12079.

[43.] Golden, R.; Gandy, J.; Vollmer, G., A review of the endocrine activity of parabens and implications for potential risks to human health. Critical reviews in toxicology 2005, 35 (5), 435-458.

[44.] Kirchhof, M. G.; de Gannes, G. C., The health controversies of parabens. Skin Therapy Lett 2013, 18 (2), 57.

[45.] Lemini, C.; Jaimez, R.; Ávila, M. E.; Franco, Y.; Larrea, F.; Lemus, A. E., In vivo and in vitro estrogen 
bioactivities of alkyl parabens. Toxicology and industrial health 2003, 19 (2-6), 69-79.

[46.] Darbre, P.; Byford, J.; Shaw, L.; Horton, R.; Pope, G.; Sauer, M., Oestrogenic activity of isobutylparaben in vitro and in vivo. Journal of Applied Toxicology 2002, 22 (4), 219-226.

[47.] Yang, H.; Thati, J.; Rasmuson, A. C., Thermodynamics of molecular solids in organic solvents. $J$. Chem. Thermodyn. 2012, 48, 150--159.

[48.] Grant, D.; Mehdizadeh, M.; Chow, A.; Fairbrother, J., Non-linear van't Hoff solubility-temperature plots and their pharmaceutical interpretation. INT J PHARM 1984, 18 (1-2), 25-38.

[49.] Giordano, F.; Bettini, R.; Donini, C.; Gazzaniga, A.; Caira, M. R.; Zhang, G. G.; Grant, D. J., Physical properties of parabens and their mixtures: solubility in water, thermal behavior, and crystal structures. J. Pharm. Sci. 1999, 88 (11), 1210-1216.

[50.] Perlovich, G. L.; Rodionov, S. V.; Bauer-Brandl, A., Thermodynamics of solubility, sublimation and solvation processes of parabens. European Journal of Pharmaceutical Sciences 2005, 24 (1), 25-33.

[51.] Andersen, F., Final Amended Report on the Safety Assessment of Methylparaben, Ethylparaben, Propylparaben, Isopropylparaben, Butylparaben, Isobutylparaben, and Benzylparaben as used in Cosmetic Products. Int. J. Toxicol. 2008, 27, 1-82.

[52.] Khan, M.; Enkelmann, V.; Brunklaus, G., Crystal engineering of pharmaceutical co-crystals: application of methyl paraben as molecular hook. Journal of the American Chemical Society 2010, 132 (14), 5254-5263.

[53.] Nicoli, S.; Zani, F.; Bilzi, S.; Bettini, R.; Santi, P., Association of nicotinamide with parabens: Effect on solubility, partition and transdermal permeation. European Journal of Pharmaceutics and Biopharmaceutics 2008, 69 (2), 613-621.

[54.] Nicoli, S.; Bilzi, S.; Santi, P.; Caira, M.; Li, J.; Bettini, R., Ethyl - paraben and nicotinamide mixtures: Apparent solubility, thermal behavior and $\mathrm{X}$ - ray structure of the 1: 1 co - crystal. J. Pharm. Sci. 2008, 97 (11), 48304839 .

[55.] Bhardwaj, R. M.; Yang, H.; Florence, A. J., Crystal structure of the co-crystal butylparaben-isonicotinamide (1/1). Acta Crystallographica Section E: Crystallographic Communications 2016, 72 (1), 53-55.

[56.] Huaiyu, Y., Crystallization of parabens: thermodynamics, nucleation and processing. 2013.

[57.] Paruta, A. N., Solubility of parabens in alcohols. $J$. Pharm. Sci. 1969, 58 (2), 216-219.

[58.] Paruta, A. N., Solubility of the Parabens in Ethanol-Water mixtures. J. Pharm. Sci. 1969, 58 (3), 364366.

[59.] Shihab, F.; Sheffield, W.; Sprowls, J.; Nematollahi, J., Solubility of alkyl benzoates I: Effect of some alkyl p hydroxybenzoates (parabens) on the solubility of benzyl p hydroxybenzoate. J. Pharm. Sci. 1970, 59 (11), 1574-1577.

[60.] Yang, H.; Rasmuson, Å. C., Solubility of Butyl Paraben in Methanol, Ethanol, Propanol, Ethyl Acetate, Acetone, and Acetonitrile. J. Chem. Eng. Data 2010, 55 (11), 5091-5093.
[61.] Yang, H.; Rasmuson, Å. C., Investigation of Batch Cooling Crystallization in a Liquid-Liquid Separating System by PAT. Org. Process Res. Dev. 2012, 16 (6), 12121224.

[62.] Yang, H.; Rasmuson, ^. C., Ternary phase diagrams of ethyl paraben and propyl paraben in ethanol aqueous solvents. FLUID PHASE EQUILIBR 2014, 376 (0), 69-75.

[63.] Unga, J.; Tajarobi, F.; Norder, O.; Frenning, G.; Larsson, A., Relating solubility data of parabens in liquid PEG 400 to the behaviour of PEG 4000-parabens solid dispersions. European journal of pharmaceutics and biopharmaceutics 2009, 73 (2), 260-268.

[64.] Tajarobi, F.; Abrahmsén - Alami, S.; Larsson, A., Dissolution rate enhancement of parabens in PEG solid dispersions and its influence on the release from hydrophilic matrix tablets. J. Pharm. Sci. 2011, 100 (1), 275-283.

[65.] Liu, J.; Rasmuson, A. C., Influence of agitation and fluid shear on primary nucleation in solution. Cryst. Growth Des. 2013, 13 (10), 4385-4394.

[66.] Liu, J.; Svärd, M.; Rasmuson, Å. C., Influence of Agitation on Primary Nucleation in Stirred Tank Crystallizers. Cryst. Growth Des. 2015.

[67.] Yang, H.; Yu, X.; Raval, V.; Makkawi, P. Y.; Florence, A., The effect of oscillatory flow on nucleation kinetics of butyl paraben. Cryst. Growth Des. 2015.

[68.] Yang, H.; ter Horst, J. H., Crystal nucleation of small organic molecules. In New Perspectives on Mineral Nucleation and Growth, Springer: 2017; pp 317-337.

[69.] Yang, H.; Florence, A. J., Relating induction time and metastable zone width. CrystEngComm 2017.

[70.] Kashchiev, D., Nucleation: basic theory with applications. Butterworth-Heinemann: 2000.

[71.] Mullin, J. W., Crystallization. ButterworthHeinemann: 2001.

[72.] Yang, H.; Rasmuson, A. C., Nucleation of Butyl Paraben in Different Solvents. Cryst. Growth Des. 2013, 13 (10), 4226-4238.

[73.] Yang, H.; Svard, M.; Zeglinski, J.; Rasmuson, А. C., Influence of Solvent and Solid-State Structure on Nucleation of Parabens. Cryst. Growth Des. 2014, 14 (8), 3890--3902.

[74.] Yang, H., Relation between metastable zone width and induction time of butyl paraben in ethanol. CrystEngComm 2014, 17 (3), 577--586.

[75.] Yang, H., Reply to the "Comment on 'Relation between metastable zone width and induction time of butyl paraben in ethanol'" by L.-D. Shiau, CrystEngComm, 2015, 17, DOI: 10.1039/C5CE00101C. CrystEngComm 2015, 17 (23), 4405-4407.

[76.] Yang, H.; Rasmuson, ^̊. C., Phase equilibrium and mechanisms of crystallization in liquid-liquid phase separating system. FLUID PHASE EQUILIBR 2015, 385, 120-128.

[77.] Yang, H.; Chen, H.; Rasmuson, Å. C., Sandwich crystals of butyl paraben. CrystEngComm 2014, 16 (37), 8863--8873.

[78.] Yang, H.; Song, C. L.; Lim, Y. X.; Chen, W.; Heng, J. Y., Selective crystallisation of carbamazepine polymorphs on surfaces with differing properties. CrystEngComm 2017, 19 (44), 6573-6578. 
[79.] Vujovic, D.; Nassimbeni, L. R., Methyl Paraben A New Polymorph? Cryst. Growth Des. 2006, 6 (7), 15951597.

[80.] Threlfall, T. L.; Gelbrich, T., The crystal structure of methyl paraben at $118 \mathrm{~K}$ does not represent a new polymorph. CRYST GROWTH DES 2007, 7 (11), 2297-2297.

[81.] Nath, N. K.; Aggarwal, H.; Nangia, A., Crystal structure of methyl paraben polymorph II. Cryst. Growth Des. 2011, 11 (4), 967-971.

[82.] Gelbrich, T.; Braun, D. E.; Ellern, A.; Griesser, U. J., Four polymorphs of methyl paraben: structural relationships and relative energy differences. Cryst. Growth Des. 2013, 13 (3), 1206-1217.

[83.] Feng, Y.; Grant, D. J. W.; Sun, C. C., Influence of crystal structure on the tableting properties of n-alkyl 4hydroxybenzoate esters (parabens). J. Pharm. Sci. 2007, 96 (12), 3324-3333.

[84.] Feng, Y.; Grant, D. J., Influence of crystal structure on the compaction properties of n-alkyl 4-hydroxybenzoate esters (parabens). Pharmaceutical research 2006, 23 (7), 1608-1616.

[85.] Docherty, R.; Clydesdale, G.; Roberts, K.; Bennema, P., Application of Bravais-Friedel-DonnayHarker, attachment energy and Ising models to predicting and understanding the morphology of molecular crystals. $J$. Phys. D: Appl. Phys. 2000, 24 (2), 89.

[86.] de Vries, E. J.; Caira, M. R.; Bogdan, M.; Farcas, S. I.; Bogdan, D., Inclusion of parabens in $\beta$-cyclodextrin: A solution NMR and X-ray structural investigation. Supramolecular Chemistry 2009, 21 (5), 358-366.

[87.] de Vries, E. J.; Caira, M. R., A structural and thermal investigation of the inclusion of parabens in heptakis (2, 6-di-O-methyl) cyclomaltoheptaose. Carbohydrate research 2008, 343 (14), 2433-2438.

[88.] Blanco, M.; Coello, J.; Iturriaga, H.; Maspoch, S.; Alaoui-Ismaili, S., UV-spectrophotometric determination of ketoprofen and paraben in a gel preparation by partial leastsquares calibration. Fresenius' journal of analytical chemistry 1997, 357 (7), 967-972.

[89.] Zhang, F.; Brinck, T.; Brandner, B. D.; Claesson, P. M.; Dedinaite, A.; Pan, J., In situ confocal Raman microspectroscopy and electrochemical studies of mussel adhesive protein and ceria composite film on carbon steel in salt solutions. Electrochimica Acta 2013, 107, 276-291.

[90.] Zhang, F.; Pan, J.; Claesson, P. M.; Brinck, T., Electrochemical, atomic force microscopy and infrared reflection absorption spectroscopy studies of pre-formed mussel adhesive protein films on carbon steel for corrosion protection. Thin Solid Films 2012, 520 (24), 7136-7143.

[91.] Zhang, F.; Sababi, M.; Brinck, T.; Persson, D.; Pan, J.; Claesson, P. M., In situ investigations of Fe3+ induced complexation of adsorbed Mefp-1 protein film on iron substrate. J. Colloid Interface. Sci. 2013, 404, 62-71.

[92.] Zhang, F.; Pan, J.; Claesson, P. M., Electrochemical and AFM studies of mussel adhesive protein (Mefp-1) as corrosion inhibitor for carbon steel. Electrochimica Acta 2011, 56 (3), 1636-1645.

[93.] Land, T. A.; Martin, T. L.; Potapenko, S.; Palmore, G. T.; De Yoreo, J. J., Recovery of surfaces from impurity poisoning during crystal growth. Nature 1999, 399 (6735), $442-445$.
[94.] Lu, J.; Rohani, S., Polymorphism and crystallization of active pharmaceutical ingredients (APIs). Current medicinal chemistry 2009, 16 (7), 884-905.

[95.] Basu, S. K.; Govardhan, C. P.; Jung, C. W.; Margolin, A. L., Protein crystals for the delivery of biopharmaceuticals. Expert opinion on biological therapy 2004, 4 (3), 301-317.

[96.] Kasprzyk-Hordern, B.; Dinsdale, R. M.; Guwy, A. J., The occurrence of pharmaceuticals, personal care products, endocrine disruptors and illicit drugs in surface water in South Wales, UK. Water Research 2008, 42 (13), 3498-3518.

[97.] Li, W.; Gao, L.; Shi, Y.; Wang, Y.; Liu, J.; Cai, Y., Spatial distribution, temporal variation and risks of parabens and their chlorinated derivatives in urban surface water in Beijing, China. Science of The Total Environment 2016, 539, 262-270.

[98.] Jonkers, N.; Sousa, A.; Galante-Oliveira, S.; Barroso, C. M.; Kohler, H.-P. E.; Giger, W., Occurrence and sources of selected phenolic endocrine disruptors in Ria de Aveiro, Portugal. Environmental Science and Pollution Research 2010, 17 (4), 834-843.

[99.] González - Mariño, I.; Quintana, J. B.; Rodríguez, I.; Cela, R., Simultaneous determination of parabens, triclosan and triclocarban in water by liquid chromatography/electrospray ionisation tandem mass spectrometry. Rapid Communications in Mass Spectrometry 2009, 23 (12), 1756-1766.

[100.] Terasaki, M.; Takemura, Y.; Makino, M., Parabenchlorinated derivatives in river waters. Environmental chemistry letters 2012, 10 (4), 401-406.

[101.] Ramaswamy, B. R.; Shanmugam, G.; Velu, G.; Rengarajan, B.; Larsson, D. J., GC-MS analysis and ecotoxicological risk assessment of triclosan, carbamazepine and parabens in Indian rivers. Journal of hazardous materials 2011, 186 (2), 1586-1593.

[102.] Renz, L.; Volz, C.; Michanowicz, D.; Ferrar, K.; Christian, C.; Lenzner, D.; El-Hefnawy, T., A study of parabens and bisphenol $\mathrm{A}$ in surface water and fish brain tissue from the Greater Pittsburgh Area. Ecotoxicology 2013, 22 (4), 632-641.

[103.] Jaworska, M.; Szulińska, Z.; Wilk, M., Application of a capillary electrophoresis method for simultaneous determination of preservatives in pharmaceutical formulations. Journal of separation science 2005, 28 (2), 137-143.

[104.] Patil, P. M.; Wankhede, S. B.; Chaudhari, P. D., Stability-indicating HPTLC method for simultaneous determination of Ketoprofen, Methyl Paraben and Propyl Paraben in gel formulation. Journal of Pharmacy Research 2013, 6 (9), 945-953.

[105.] Canosa, P.; Pérez-Palacios, D.; Garrido-López, A.; Tena, M.; Rodríguez, I.; Rubí, E.; Cela, R., Pressurized liquid extraction with in-cell clean-up followed by gas chromatography-tandem mass spectrometry for the selective determination of parabens and triclosan in indoor dust. Journal of Chromatography A 2007, 1161 (1), 105-112.

[106.] Kobos, R., Enzyme-based electrochemical biosensors. TrAC Trends in Analytical Chemistry 1987, 6 (1), 6-9. 
[107.] Qurashi, A.; Rather, J. A.; Yamazaki, T.; Sohail, M.; De Wael, K.; Merzougui, B.; Hakeem, A. S., Swift electrochemical detection of paraben an endocrine disruptor by In 2 O 3 nanobricks. Sensors and Actuators B: Chemical 2015, 221, 167-171.

[108.] Jacobs, C. B.; Peairs, M. J.; Venton, B. J., Review: Carbon nanotube based electrochemical sensors for biomolecules. Analytica Chimica Acta 2010, 662 (2), 105127.

[109.] Liu, F.; Piao, Y.; Choi, J. S.; Seo, T. S., Threedimensional graphene micropillar based electrochemical sensor for phenol detection. Biosensors and Bioelectronics 2013, 50, 387-392.

[110.] Sanghavi, B. J.; Varhue, W.; Chávez, J. L.; Chou, C.-F.; Swami, N. S., Electrokinetic preconcentration and detection of neuropeptides at patterned graphene-modified electrodes in a nanochannel. Analytical chemistry 2014, 86 (9), 4120-4125.

[111.] Frontistis, Z.; Antonopoulou, M.; Yazirdagi, M.; Kilinc, Z.; Konstantinou, I.; Katsaounis, A.; Mantzavinos, D., Boron-doped diamond electrooxidation of ethyl paraben: The effect of electrolyte on by-products distribution and mechanisms. Journal of Environmental Management 2016.

[112.] Altria, K.; Kelly, M.; Clark, B., Current applications in the analysis of pharmaceuticals by capillary electrophoresis. II. TrAC Trends in Analytical Chemistry 1998, 17 (4), 214-226.

[113.] Gholivand, M. B.; Shamsipur, M.; Dehdashtian, S.; Rajabi, H. R., Development of a selective and sensitive voltammetric sensor for propylparaben based on a nanosized molecularly imprinted polymer-carbon paste electrode. Materials Science and Engineering: C 2014, 36, 102-107.

[114.] Cabaleiro, N.; De La Calle, I.; Bendicho, C.; Lavilla, I., Current trends in liquid-liquid and solid-liquid extraction for cosmetic analysis: a review. Analytical Methods 2013, 5 (2), 323-340.

[115.] Canosa, P.; Rodriguez, I.; Rubí, E.; Cela, R., Optimization of solid-phase microextraction conditions for the determination of triclosan and possible related compounds in water samples. Journal of Chromatography A 2005, 1072 (1), 107-115.

[116.] Zhao, R. S.; Yuan, J. P.; Li, H. F.; Wang, X.; Jiang, T.; Lin, J. M., Nonequilibrium hollow-fiber liquid-phase microextraction with in situ derivatization for the measurement of triclosan in aqueous samples by gas chromatography-mass spectrometry. Analytical and Bioanalytical Chemistry 2007, 387 (8), 2911-2915.

[117.] Pérez, R.; Albero, B.; Miguel, E.; Sánchez-Brunete, C., Determination of parabens and endocrine-disrupting alkylphenols in soil by gas chromatography-mass spectrometry following matrix solid-phase dispersion or incolumn microwave-assisted extraction: a comparative study. Analytical and bioanalytical chemistry 2012, 402 (7), 23472357.

[118.] Regueiro, J.; Llompart, M.; Psillakis, E.; GarciaMonteagudo, J. C.; Garcia-Jares, C., Ultrasound-assisted emulsification-microextraction of phenolic preservatives in water. Talanta 2009, 79 (5), 1387-1397.

[119.] Kazandjian, R. Z.; Klibanov, A. M., Regioselective oxidation of phenols catalyzed by polyphenol oxidase in chloroform. Journal of the American Chemical Society 1985, 107 (19), 5448-5450.

[120.] Márquez-Sillero, I.; Aguilera-Herrador, E.; Cárdenas, S.; Valcárcel, M., Determination of parabens in cosmetic products using multi-walled carbon nanotubes as solid phase extraction sorbent and corona-charged aerosol detection system. Journal of Chromatography A 2010, 1217 (1), 1-6.

[121.] Beltran, A.; Marcé, R.; Cormack, P.; Borrull, F., Synthetic approaches to parabens molecularly imprinted polymers and their applications to the solid-phase extraction of river water samples. Analytica chimica acta 2010, 677 (1), $72-78$.

[122.] Piao, C.; Chen, L.; Wang, Y., A review of the extraction and chromatographic determination methods for the analysis of parabens. Journal of Chromatography B 2014, 969, 139-148.

[123.] Bello-López, M. Á.; Ramos-Payán, M.; OcañaGonzález, J. A.; Fernández-Torres, R.; Callejón-Mochón, M., Analytical applications of hollow fiber liquid phase microextraction (HF-LPME): a review. Analytical Letters 2012, 45 (8), 804-830.

[124.] Ocaña-González, J. A.; Villar-Navarro, M.; RamosPayán, M.; Fernández-Torres, R.; Bello-López, M. A., New developments in the extraction and determination of parabens in cosmetics and environmental samples. A review. Analytica chimica acta 2015, 858, 1-15.

[125.] Tavares, R. S.; Martins, F. C.; Oliveira, P. J.; Ramalho-Santos, J.; Peixoto, F. P., Parabens in male infertility-Is there a mitochondrial connection? Reproductive Toxicology 2009, 27 (1), 1-7.

[126.] Janjua, N. R.; Mortensen, G. K.; Andersson, A.-M.; Kongshoj, B.; Skakkebæk, N. E.; Wulf, H. C., Systemic uptake of diethyl phthalate, dibutyl phthalate, and butyl paraben following whole-body topical application and reproductive and thyroid hormone levels in humans. Environmental science \& technology 2007, 41 (15), 55645570.

[127.] Harvey, P. W.; Everett, D. J., Regulation of endocrine-disrupting chemicals: critical overview and deficiencies in toxicology and risk assessment for human health. Best Practice \& Research Clinical Endocrinology \& Metabolism 2006, 20 (1), 145-165.

[128.] Braun, J. M.; Just, A. C.; Williams, P. L.; Smith, K. W.; Calafat, A. M.; Hauser, R., Personal care product use and urinary phthalate metabolite and paraben concentrations during pregnancy among women from a fertility clinic. Journal of Exposure Science and Environmental Epidemiology 2014, 24 (5), 459-466.

[129.] Nishihama, Y.; Yoshinaga, J.; Iida, A.; Konishi, S.; Imai, H.; Yoneyama, M.; Nakajima, D.; Shiraishi, H., Association between paraben exposure and menstrual cycle in female university students in Japan. Reproductive Toxicology 2016, 63, 107-113.

[130.] Darbre, P.; Aljarrah, A.; Miller, W.; Coldham, N.; Sauer, M.; Pope, G., Concentrations of parabens in human breast tumours. Journal of applied toxicology 2004, 24 (1), $5-13$.

[131.] Decker, A. H., Associations between Butylparaben and Thyroid Levels in Females Aged 12 and over (NHANES, 2007-2008). 2015. 
[132.] Prusakiewicz, J. J.; Harville, H. M.; Zhang, Y.; Ackermann, C.; Voorman, R. L., Parabens inhibit human skin estrogen sulfotransferase activity: possible link to paraben estrogenic effects. Toxicology 2007, 232 (3), 248256.

[133.] Ellsworth, D. L.; Ellsworth, R. E.; Liebman, M. N.; Hooke, J. A.; Shriver, C. D., Genomic instability in histologically normal breast tissues: implications for carcinogenesis. The lancet oncology 2004, 5 (12), 753-758.

[134.] Lengauer, C.; Kinzler, K. W.; Vogelstein, B., Genetic instabilities in human cancers. Nature 1998, 396 (6712), 643-649.

[135.] Oettel, M.; Schillinger, E., Estrogens and Antiestrogens I: Physiology and Mechanisms of Action of Estrogens and Antiestrogens. Springer Science \& Business Media: 2012.

[136.] Towers, C. V.; Terry, P. D.; Lewis, D.; Howard, B.; Chambers, W.; Armistead, C.; Weitz, B.; Porter, S.; Borman, C. J.; Kennedy, R. C., Transplacental passage of antimicrobial paraben preservatives. Journal of Exposure Science and Environmental Epidemiology 2015, 25 (6), 604607.

[137.] Ishiwatari, S.; Suzuki, T.; Hitomi, T.; Yoshino, T.; Matsukuma, S.; Tsuji, T., Effects of methyl paraben on skin keratinocytes. Journal of applied toxicology 2007, 27 (1), 19.

[138.] Darbre, P. D.; Harvey, P. W., Paraben esters: review of recent studies of endocrine toxicity, absorption, esterase and human exposure, and discussion of potential human health risks. Journal of applied toxicology 2008, 28 (5), 561-578.
[139.] Darbre, P.; Byford, J.; Shaw, L.; Hall, S.; Coldham, N.; Pope, G.; Sauer, M., Oestrogenic activity of benzylparaben. Journal of Applied Toxicology 2003, 23 (1), 43-51.

[140.] Soto, A. M.; Maffini, M. V.; Schaeberle, C. M.; Sonnenschein, C., Strengths and weaknesses of in vitro assays for estrogenic and androgenic activity. Best Practice \& Research Clinical Endocrinology \& Metabolism 2006, 20 (1), 15-33.

[141.] Clode, S., Assessment of in vivo assays for endocrine disruption. Best Practice \& Research Clinical Endocrinology \& Metabolism 2006, 20 (1), 35-43.

[142.] Ritzau, M.; Swangsilpa, K., Prophylactic use of phydroxybenzoic acid propylester to prevent dry sockets. Tandlaegebladet 1975, 79 (20), 800.

[143.] Song, C.; Lin, J.; Huang, X.; Wu, Y.; Liu, J.; Wu, C., Effect of butyl paraben on the development and microbial composition of periphyton. Ecotoxicology 2016, 25 (2), 342-349.

[144.] Koeppe, E. S.; Ferguson, K. K.; Colacino, J. A.; Meeker, J. D., Relationship between urinary triclosan and paraben concentrations and serum thyroid measures in NHANES 2007-2008. Science of the Total Environment 2013, 445, 299-305.

[145.] Soni, M.; Taylor, S.; Greenberg, N.; Burdock, G., Evaluation of the health aspects of methyl paraben: a review of the published literature. FOOD CHEM TOXICOL 2002, 40 (10), 1335-1373.

[146.] Renz, L. M. A study of xenoestrogens in the Greater Pittsburgh Area. University of Pittsburgh, 2011. 